\title{
Prevalence of asthma and allergies in 13-14-year-old adolescents from Luanda, Angola
}

\author{
M. Arrais, ${ }^{*}$ O. Lulua,* F. Quifica,* J. Rosado-Pinto, ${ }^{\dagger}$ J. M. R. Gama, ${ }^{\ddagger}$ L. Taborda-Barata\$ึ \\ *Military Hospital, Luanda, Angola; 'Department of Immunoallergology, Hospital da Luz, Lisbon, ${ }^{\ddagger}$ Department of \\ Mathematics, Faculty of Sciences, University of Beira Interior, Covilhã, §'Department of Allergy \& Clinical \\ Immunology, Cova da Beira Hospital, Covilhã, "Centro de Investigação em Ciências da Saúde, University of Beira \\ Interior, Covilhã, Portugal
}

S U M M AR Y

SETTING: The few epidemiological studies on asthma and allergic diseases performed in Africa have shown that the prevalence of these diseases is high or increasing. No such studies have been performed in Angola. OBJECTIVE: To determine the prevalence of asthma and other allergic diseases in Angolan adolescents. DESIGN: This was a descriptive, observational, crosssectional study in the province of Luanda, Angola, using the International Study of Asthma and Allergies in Childhood study methodology in adolescents aged 13 and 14 years. Twenty-three (12\%) public schools were randomly selected. Data were analysed using the Statistical Package for the Social Sciences version 22.0 software.

RESULTS: A total of 3128 adolescents were included. The prevalence of asthma (wheezing in the previous 12 months) was $13.4 \%$. The prevalence of rhinitis (sneezing, runny or blocked nose in the previous 12 months) was $27 \%$ and that of eczema (itchy skin lesions in the previous 12 months) was $20 \%$; both were more prevalent in girls. Rhinitis was associated with a greater number of episodes of night cough in adolescents with asthma. Rhinitis and eczema, a split-type air conditioning system, and frequent intake (more than once per month) of paracetamol were associated with a higher risk of having asthma.

CONCLUSION: Asthma and related allergic diseases are a public health problem in adolescents from Luanda. Preventive and control measures should be implemented.

K EY WORD S: adolescents; Angola; asthma; prevalence; risk factors
ASTHMA is an important cause of morbidity and mortality worldwide, and there is evidence that the global burden of asthma has been increasing over the past 20 years. ${ }^{1}$ The International Study of Asthma and Allergies in Childhood (ISAAC), which was repeated within a 8-10 year interval (comparison between ISAAC Phases I and III) using a standardised and validated methodology, showed that despite clear differences in prevalence values of asthma and allergic diseases among participating countries, asthma prevalence is also increasing in children and adolescents, particularly in those countries that had a lower prevalence in Phase I. ${ }^{2,3}$

Few epidemiological studies have been performed in Africa, but ISAAC results in participating countries have shown that prevalence values for asthma also vary significantly. For the 13-14-year-old age group, the lowest values were found in Algeria (Phase I, $5.9 \%$; Phase III, $8.7 \%$ ), whereas the highest values were detected in South Africa (Phase I, 16.1\%; Phase III, $20.3 \%) .^{2}$ The ISAAC Phase III study showed that, with the exception of Ethiopia and Morocco, the prevalence of asthma is also increasing in Africa, particularly among 13 - and 14-year-olds. ${ }^{2,3}$ In Angola, respiratory diseases are one of the leading causes for visits to emergency units, mostly among children and adolescents. However, no studies have previously been published on the prevalence of asthma and other allergic diseases in children or adolescents in Angola.

We decided to study the prevalence of asthma and allergic diseases in 13-14-year-old adolescents from the most populated city in Angola, Luanda.

\section{METHODS}

\section{Population sample}

This was a cross-sectional study performed in the province of Luanda, Angola, between August and November 2014, in 13-14-year-old adolescents. The province has 18 districts and a population of 6542944 , representing $27 \%$ of the country's popu-

Correspondence to: Professor Luis Taborda-Barata, Centro de Investigação em Ciências da Saúde, Faculty of Health Sciences, University of Beira Interior, Avenida Infante D Henrique, 6200-506 Covilhã, Portugal. e-mail: tabordabarata@ fcsaude.ubi.pt

Article submitted 12 July 2016. Final version accepted 20 February 2017. 
lation. Luanda is the capital and includes seven boroughs, in which $97.5 \%$ of the population resides in urban areas. In Luanda, $23(12 \%)$ public schools were randomly selected out of a total of 186 , and an average of 4-5 classes in each school were randomly selected to analyse at least 3000 adolescents, in agreement with the ISAAC study protocol. ${ }^{4}$

\section{Written questionnaires}

Data were collected using the Portuguese version of the ISAAC questionnaire, ${ }^{4,5}$ which includes questions on symptoms of asthma, allergic rhinitis and eczema. The ISAAC environmental exposure and risk factor questionnaire for 13-14-year-olds was also used. ${ }^{6}$ All questions and explanations about the questionnaire were provided in a standardised fashion in Portuguese.

Current asthma was based upon positive replies to the question 'In the past 12 months have you had wheezing in your chest?', as defined in the ISAAC Phase III Protocol. 7 Study adolescents also answered questions on the number of wheezing episodes, whether these interfered with sleep or speech or were related to physical exercise, as well as on episodes of nocturnal cough in the previous 12 months.

Current rhinitis was based upon sneezing bouts, rhinorrhoea or nasal obstruction in the absence of influenza in the previous 12 months. Adolescents with symptoms of rhinitis and conjunctivitis were regarded as having rhinoconjunctivitis, and were asked whether symptoms interfered with their daily activities and whether they had ever had 'hay fever'.

Cutaneous lesions with pruritus which waxed and waned in the previous 12 months were regarded as eczema. Further questions were also asked in terms of the location of the lesions and interference with sleep.

The questionnaire on environmental exposure focused on the fuel used for cooking, type of indoor home-cooling device used, frequency of the passage of trucks in front of homes, presence of cats and dogs at home, passive exposure to tobacco smoke, frequency of use of anti-inflammatory drug paracetamol and number of siblings living in the home.

\section{Measurement of lung function using a peak flow meter}

Peak flow meter recordings (Mini-Wright Peak Flow Meter, Clement-Clarke, Harlow, UK) were made in adolescents with symptoms of current asthma. Those with signs or symptoms of infectious acute respiratory illness were excluded from this analysis. Readings were taken in triplicate with the adolescent sitting down, and the highest value was recorded only if the coefficient of variation was low. As there are no reference values for peak expiratory flow (PEF) in Angolan adolescents, we used values from Brazilian adolescents $^{8}$ to calculate per cent predicted values and compared them with ranges of reference values
$(>80 \%, 50-80 \%$ or $<50 \%)$. We considered current asthma when current asthma symptoms were associated with PEF values below $80 \%$ predicted.

\section{Height and weight measurements}

Height was measured using a portable $200 \mathrm{~cm}$ stadiometer, accurate to $0.1 \mathrm{~cm}$ (SECA 123; SECA, Hamburg, Germany) and recorded in cm. Adolescents had their backs turned to the stadiometer and their heads were positioned in the Frankfurt horizontal plane. Weight was measured using portable calibrated scales with a $150 \mathrm{~kg}$ capacity and $0.1 \mathrm{~kg}$ precision (SECA 780 digital scale; SECA) and recorded in $\mathrm{kg}$. For both measurements, adolescents were asked to stand upright with no shoes.

\section{Calculation of body mass index}

Body mass index (BMI) was calculated using the standard formula: weight (in $\mathrm{kg}$ )/height (in $\mathrm{m}^{2}$ ). As there are no BMI reference values for Angola, adolescents were classified as 'underweight', 'normal weight', 'overweight' or 'obese', in accordance with World Health Organization definitions of BMI values. ${ }^{9}$

\section{Ethical considerations}

The study protocol was approved by the Ethics Committees of the Angolan Ministry of Health and the Faculty of Health Sciences, University of Beira Interior, Portugal. It was also approved by the Provincial Board of Education, Luanda, Angola, and by the Directors of the selected schools. All subjects and their parents signed a written consent form.

\section{Statistical analysis}

Data were analysed using the Software Package for Social Sciences $\left(\right.$ SPSS $^{\circledR}$ ) version 22.0 (IBM Corp, Armonk, NY, USA). Descriptive analysis was used to characterise the sample. Prevalence values were estimated by dividing the number of positive responses to the questions selected for the diagnosis by the number of completed questionnaires. Proportions were compared using the $\chi^{2}$ test or Fisher's exact test, as appropriate. Odds ratios (ORs) were calculated to characterise the role of environmental factors as possible risk factors for asthma. A logistic regression model was developed using the logit function. For categorical variables, the 'normal' situation was defined as the reference category, and odds were estimated for other categories against the reference category. Quality and assumptions of the model were tested using the Omnibus and Hosmer-Lemeshow tests, as well as by analysis of residuals and outliers. A receiver operating characteristic (ROC) curve analysis of the model was also carried out. $P<0.05$ was regarded as significant with all two-tailed statistical tests. 
Table 1 Sociodemographic data of study sample of 13-14-year-old adolescents from Luanda, Angola

\begin{tabular}{lc}
\hline & Total \\
Parameter & $n(\%)$ \\
\hline Boys:girls & $1432(45.8): 1696(54.2)$ \\
Urban:rural, \% & $100: 0$ \\
Boroughs & \\
$\quad$ Luanda & $1631(52)$ \\
Belas & $513(16.4)$ \\
Cacuaco & $104(3.3)$ \\
Viana & $443(14.1)$ \\
Icolo e Bengo & $70(2.2)$ \\
$\quad$ Cazenga & $367(11.7)$ \\
Social status and income & \\
High & $641(20.5)$ \\
$\quad$ Medium & $1408(45.0)$ \\
$\quad$ Low & $1079(34.5)$ \\
Parental schooling & \\
Primary school (up to 4 years) & $1555(49.7)$ \\
Intermediate school (up to 10 years) & $963(30.8)$ \\
High school (up to 14 years) & $607(19.4)$ \\
\hline
\end{tabular}

\section{RESULTS}

\section{Demographics}

From the sample of 3317 adolescents from 23 selected schools, we obtained 3128 valid questionnaires $(94 \%$ reply rate). There was no concentration of non-responders or responders with invalidated questionnaires in any specific school or set of schools. Of the 3128 validated questionnaires, 1696 (54.2\%) responders were female and 1432 were male $(45.8 \%)$. Sex and age distributions were similar to those in the 189 non-responders or responders with invalid questionnaires. Sociodemographic data are shown in Table 1.

\section{Prevalence of asthma-like symptoms}

Approximately $26 \%$ of the adolescents reported that they had already experienced wheezing episodes at some time in their lives (Table 2). However, based upon the presence of wheezing in the last 12 months, the prevalence of current asthma was $13.4 \%$ (95\% confidence interval [CI] 12.3-14.7), with no significant differences between boys and girls. Overall, 22\% of the adolescents reported experiencing wheeze during or after physical exercise, and 39\% reported episodes of nocturnal dry cough, not associated with respiratory infections in the previous 12 months (Table 2).

The prevalence of symptoms such as 'wheezing ever', 'wheezing with physical exercise in the last 12 months' and 'nocturnal cough in the last 12 months' was significantly higher in girls than in boys.

No adolescent had ever been seen by a specialist physician for asthma symptoms. Only $5 \%$ of the adolescents reporting wheezing in the last 12 months had been prescribed a $\beta_{2}$-agonist at an emergency department.

\section{Prevalence of rhinitis}

The prevalence of current rhinitis was approximately $27 \%$ (95\% CI 25.5-28.6), and that of current rhinoconjunctivitis was around $18 \%$ (Table 2); $18 \%$ of the adolescents reported that their nasal symptoms interfered with their daily activities, and this occurred more frequently in girls than in boys $(62 \%$ vs. $38 \%, P$ $=0.04, \chi^{2}$ test $)$. Around one third of the adolescents reported that they had ever experienced hay fever; this was also more frequent in girls.

\section{Prevalence of eczema}

Having an itchy rash or eczema 'ever' was reported by almost $28 \%$ of the adolescents (Table 2). Lesions affected specific areas of the body in $16 \%$ of the adolescents and disappeared, at least temporarily, in around $13 \%$ of the cases. Just over $20 \%$ (95\% CI

Table 2 Prevalence of asthma, rhinitis and eczema

\begin{tabular}{|c|c|c|c|c|}
\hline & $\begin{array}{c}\text { Total } \\
n(\%)\end{array}$ & $\begin{array}{c}\text { Female } \\
n(\%)\end{array}$ & $\begin{array}{l}\text { Male } \\
n(\%)\end{array}$ & $P$ value \\
\hline \multicolumn{5}{|l|}{ Bronchial asthma } \\
\hline Wheezing ever & $817(26.1)$ & $485(28.6)$ & $332(23.2)$ & $<0.001$ \\
\hline Wheezing in last 12 months & $422(13.4)$ & $256(15.1)$ & $166(11.6)$ & 0.004 \\
\hline Asthma ever & $482(15.4)$ & $271(16.0)$ & $211(14.7)$ & 0.337 \\
\hline Exercise-induced wheezing in last 12 months & $685(21.8)$ & $422(24.9)$ & $263(18.4)$ & $<0.001$ \\
\hline Nocturnal cough last 12 months & $1233(39.4)$ & $726(42.8)$ & $507(35.4)$ & $<0.001$ \\
\hline \multicolumn{5}{|l|}{ Rhinitis } \\
\hline Sneezing, runny or blocked nose ever & $1267(40.5)$ & $717(42.3)$ & $550(38.4)$ & 0.017 \\
\hline $\begin{array}{l}\text { Sneezing, runny or blocked nose in last } \\
12 \text { months }\end{array}$ & $844(26.9)$ & $503(29.7)$ & $341(23.8)$ & $<0.001$ \\
\hline Rhinoconjunctivitis in last 12 months & $570(18.2)$ & $378(22.3)$ & $192(13.4)$ & $<0.001$ \\
\hline Interference with activities in last 12 months & $573(18.3)$ & $353(20.8)$ & $220(15.4)$ & 0.044 \\
\hline Hay fever ever & $952(30.4)$ & $593(35.0)$ & $359(25.1)$ & $<0.001$ \\
\hline \multicolumn{5}{|l|}{ Eczema } \\
\hline Itchy rash ever & $868(27.7)$ & $508(30.0)$ & $360(25.1)$ & 0.003 \\
\hline Itchy rash in last 12 months & $633(20.2)$ & $381(22.5)$ & $252(17.6)$ & $<0.001$ \\
\hline Itchy flexural areas & $493(15.7)$ & $303(17.9)$ & $190(13.3)$ & $<0.001$ \\
\hline Clearance of rash in last 12 months & $420(13.4)$ & $239(14.1)$ & $181(12.6)$ & 0.013 \\
\hline Interference with sleep in last 12 months & $407(13.0)$ & $261(15.4)$ & $146(10.2)$ & 0.036 \\
\hline Eczema ever & $769(24.5)$ & $479(28.2)$ & $290(20.3)$ & $<0.001$ \\
\hline
\end{tabular}


Table 3 Clinical features of asthma in adolescents with asthma symptoms ('wheezing in the last 12 months',$n=422$ )

\begin{tabular}{|c|c|c|c|c|}
\hline & $\begin{array}{l}\text { Total } \\
n(\%)\end{array}$ & $\begin{array}{c}\text { Female } \\
n(\%)\end{array}$ & $\begin{array}{l}\text { Male } \\
n(\%)\end{array}$ & $P$ value \\
\hline \multicolumn{5}{|l|}{ Wheezing episodes in last 12 months } \\
\hline $1-3$ & $300(71.1)$ & $185(72.3)$ & $115(69.3)$ & 0.566 \\
\hline $4-12$ & $74(17.5)$ & $44(17.2)$ & $30(18.1)$ & 0.815 \\
\hline$>12$ & $48(11.4)$ & $27(10.5)$ & $21(12.7)$ & 0.506 \\
\hline \multicolumn{5}{|l|}{ Sleep disturbance episodes in last 12 months } \\
\hline None & 88 (20.9) & $40(15.6)$ & $48(28.9)$ & 0.001 \\
\hline$<1 /$ week & $234(55.5)$ & $153(59.8)$ & $81(48.8)$ & 0.027 \\
\hline$\geqslant 1 /$ week & $100(23.7)$ & $63(24.6)$ & $37(22.3)$ & 0.584 \\
\hline Speech affected in last 12 months & $218(51.7)$ & $139(54.3)$ & $79(47.6)$ & 0.178 \\
\hline Asthma ever & $150(35.5)$ & $89(34.8)$ & $61(36.7)$ & 0.678 \\
\hline Exercise-induced wheezing in last 12 months & $242(57.3)$ & $154(60.2)$ & $88(53.0)$ & 0.147 \\
\hline Nocturnal cough in last 12 months & $283(67.1)$ & $174(68.0)$ & $109(65.7)$ & 0.622 \\
\hline \multicolumn{5}{|l|}{ Peak flow recordings (\% predicted) } \\
\hline$>80 \%$ & $381(90.3)$ & $227(88.7)$ & $154(92.8)$ & \\
\hline $50-80 \%$ & $40(9.5)$ & $29(11.3)$ & $11(6.6)$ & $0.087 *$ \\
\hline$<50 \%$ & $1(0.2)$ & 0 & $1(0.6)$ & \\
\hline
\end{tabular}

18.9-21.7) of all the adolescents reported that they had had pruritic lesions in the last 12 months, and about $13 \%$ reported that their lesions interfered with their sleep. Again, girls were more frequently affected than boys.

\section{Details of respiratory symptoms and respiratory} function in adolescents with probable current asthma

Of the 422 adolescents reporting wheezing episodes in the last 12 months (current asthma), most (71.1\%) had had only 1-3 episodes (Table 3 ). However, almost $12 \%$ reported more than 12 episodes and only $21 \%$ of the adolescents reported not waking up during the night because of respiratory symptoms in

Table 4 Associations between the presence of rhinitis in the last 12 months and clinical asthma parameters in adolescents with asthma symptoms (wheezing episodes in the last 12 months, $n=422$ )

\begin{tabular}{|c|c|c|c|c|}
\hline & \multicolumn{2}{|c|}{$\begin{array}{c}\text { Rhinitis in } \\
\text { last } 12 \text { months }\end{array}$} & \multirow[b]{2}{*}{ OR $(95 \% \mathrm{Cl})^{\star}$} & \multirow[b]{2}{*}{$P$ value } \\
\hline & Yes & No & & \\
\hline \multicolumn{5}{|c|}{ Wheezing episodes in last 12 months } \\
\hline 0 & 1 & 0 & & \\
\hline $1-3$ & 166 & 133 & 1 & \\
\hline $4-12$ & 42 & 32 & $1.05(0.63-1.76)$ & 0.848 \\
\hline$>12$ & 35 & 13 & $2.16(1.10-4.24)$ & 0.026 \\
\hline \multicolumn{5}{|c|}{ Sleep disturbance episodes in last 12 months } \\
\hline 0 & 43 & 45 & 1 & \\
\hline$<1 /$ week & 136 & 98 & $1.45(0.89-2.38)$ & 0.137 \\
\hline$\geqslant 1 /$ week & 65 & 35 & $1.94(1.08-3.49)$ & 0.026 \\
\hline \multicolumn{5}{|c|}{ Nocturnal cough in last 12 months } \\
\hline & 53 & 86 & 1 & \\
\hline Yes & 191 & 92 & $3.37(2.21-5.14)$ & $<0.001$ \\
\hline \multicolumn{5}{|c|}{ Peak flow recordings ( $\%$ predicted) } \\
\hline$>80 \%$ & 216 & 165 & 1 & \\
\hline $50-80 \%$ & 27 & 13 & $1.65(0.83-3.28)$ & 0.191 \\
\hline$<50 \%$ & 1 & 0 & & \\
\hline
\end{tabular}

* For each categorical variable, the 'normal' situation was defined as the reference category and odds were estimated for the other categories against the reference category.

$\mathrm{OR}=$ odds ratio; $\mathrm{Cl}=$ confidence interval. the previous 12 months. Furthermore, a high proportion $(52 \%)$ reported episodes of wheezing that interfered with speech, $57 \%$ had had wheezing episodes during or after physical exercise and 67\% reported dry cough during the night, not associated with respiratory infections. Finally, PEF recordings showed that almost $10 \%$ had a moderate degree of obstruction and $1 \%$ had severe obstruction (Table 3), suggesting a prevalence of confirmed current asthma of $1.3 \%$.

\section{Influence of rhinitis symptoms upon asthma symptoms}

Among the 422 adolescents with current asthma, the presence of rhinitis in the last 12 months was associated with a trend towards a higher number of episodes of nocturnal cough $(P=0.084$, Fisher's exact; Table 4). Having current rhinitis symptoms increased the risk of having a high number $(>12)$ of wheezing episodes by two-fold and the risk of having nocturnal episodes of dry cough by about three-fold (OR 3.37).

\section{Risk factors for asthma}

Using univariate analysis, the presence of symptoms of rhinitis in the previous 12 months, a history of eczema ever, the type of home cooling system, excessive intake of paracetamol and the presence of a dog at home were significantly associated with the presence of asthma (data not shown). However, logistic regression analysis only confirmed rhinitis, eczema, a split air-conditioning (AC) type of cooling system and high intake of paracetamol (more than once per month) as significant risk factors (Table 5). ROC analysis showed that the logistic model had an acceptable discriminatory capacity (ROC 0.735, 95\% CI for true area 0.709-0.760, a maximal sensitivity of $73.5 \%$ and specificity of $65.2 \%$ for a threshold value of 0.094). 


\section{DISCUSSION}

This was the first study on asthma prevalence in Angolan adolescents, and it yielded a value of $13.4 \%$, with no statistically significant differences between boys and girls; $9 \%$ of asthma patients had moderate bronchial obstruction. The prevalence of rhinitis was $27 \%$, and that of eczema was $20 \%$; both were more prevalent in girls. Rhinitis was associated with more symptomatic asthma. Rhinitis and eczema, use of a split AC system for home cooling and frequent intake of paracetamol were significantly associated with an increased risk of asthma.

We followed the ISAAC methodology in a random sample of more than 3000 adolescents, obtaining a very high response rate $(94 \%)$, and used the question on 'wheezing episodes in the last 12 months' for the diagnosis of current asthma, as it is known to have high sensitivity for the purpose. ${ }^{10,11}$ The prevalence of asthma in our study $(13.4 \%)$ is in the mid-range of values observed in the ISAAC study, which varied between 3.4 (Albania) and 31.2\% (UK) ${ }^{2}$ in Phase III, and is similar to the mean of African prevalence values $(14.5 \%))^{2,12}$ In Africa, asthma prevalence in Angola is higher than in Cameroon $(5.7 \%)$ or the Democratic Republic of Congo $(7.5 \%) ;^{12,13}$ it is similar to that in Mozambique (13.3\%), ${ }^{14}$ but lower than that in South Africa (Cape Town 20.3\%, Polokwane 18.0\%), or Reunion Island $(21.5 \%) .{ }^{22,13}$ As these studies used the same questionnaire, genetic, environmental or lifestyle differences may account for the discrepancies observed. ${ }^{13}$ However, we may have underestimated asthma prevalence, as some adolescents were unfamiliar with the concept of 'wheezing' and symptom recognition may be poor or not well accepted. ${ }^{14}$ The prevalence of nocturnal cough in our study was higher than that in most African countries, ${ }^{13-15}$ although it is likely that it was not always associated with asthma.

The prevalence of current rhinoconjuntivitis $(18.2 \%)$ places Angola in the middle range of values for African countries, close to the mean prevalence $(18.1 \%)$ in the top one third of participating countries. $2,13,16$ In Africa, it is lower than in the Ivory Coast $(27.6 \%)$ or Congo Brazzaville $(33.3 \%),{ }^{13}$ but is higher than in Cameroon $(8.9 \%)$ or Ethiopia $(9.9 \%),{ }^{13}$ suggesting that the described relationship between income per capita and the prevalence of rhinoconjunctivitis ${ }^{16}$ may not apply. One third of the adolescents reported having ever experienced hay fever, but this suggests that symptoms may have been overestimated because the term 'hay fever' is hard to understand in regions without a clear pollen season, as in Luanda.

The prevalence of current eczema in our study $(20.2 \%)$ is higher than that observed in most African countries, ${ }^{13}$ and much higher than the mean world prevalence of $7.3 \%, 2,12,17$ although it is lower than in various Asian and South American countries. ${ }^{17}$ In the
ISAAC study, the highest prevalence of eczema came from scattered areas, including some in Scandinavia and Africa that were not among areas with the highest asthma prevalence. ${ }^{18}$ Luanda seems to fit this pattern for reasons that remain to be ascertained. Although eczema is a significant public health problem in developing countries, ${ }^{17}$ it is possible that non-eczema-related manifestations may have been reported, as observed in other studies. ${ }^{14}$

We further characterised the clinical aspects of adolescents with bronchial asthma. Almost 12\% reported more than 12 episodes of wheezing in the previous year, and almost a quarter had frequent sleep disturbance episodes. Furthermore, a high percentage $(52 \%)$ had episodes of wheezing that interfered with speech, as has also been reported in other countries. $5,7,12-15$ The presence of rhinitis was associated with more episodes of nocturnal cough and wheezing. Finally, almost $10 \%$ had a moderate degree of bronchial obstruction. Our results show that a high proportion of adolescents with asthma in Luanda are symptomatic.

We identified disease-related risk factors for the presence of asthma. In the total sample of adolescents, rhinitis increased the risk of having asthma by almost five fold, as reported in other countries. ${ }^{19-22}$ Rhinitis is a known risk factor for asthma. ${ }^{23}$ We also identified eczema as another risk factor, in accordance with reports showing a relationship between the early onset of atopic eczema and subsequent respiratory disease in schoolchildren. ${ }^{24,25}$

We also identified environmental risk factors for asthma. Using a split AC system was a risk factor, possibly because cleaning these devices is difficult, which may lead to the accumulation of allergens and other substances. ${ }^{26}$ In China, air conditioning systems are also significantly associated with asthma in schoolchildren, ${ }^{27}$ although these systems may protect against traffic-related exposures at home, as reported in Singaporean children. ${ }^{28}$

Finally, a high frequency of paracetamol intake was a risk factor for asthma in our study, which is in agreement with global ISAAC findings. ${ }^{29,30}$ This has also been described as a risk factor for rhinoconjunctivitis and eczema in a setting of multimorbidity, ${ }^{30}$ probably due to various mechanisms. ${ }^{31}$ In Angola, this association may be due to paracetamol being frequently taken not only for febrile respiratory problems, but also for malaria.

Our study had various limitations. It was based on self-reports of symptoms and is therefore subject to various types of bias, although the ISAAC approach ensures that reported symptoms significantly reflect the clinical situation. ${ }^{32}$ Some adolescents were not familiar with some of the terms used in the questionnaire, as has been observed in some other ISAAC studies. Another source of bias may have been the fact that all children were from urban areas of the 
Table 5 Risk factors for probable asthma (wheezing in last 12 months)

\begin{tabular}{|c|c|c|c|c|c|}
\hline Risk factors & $\begin{array}{l}\text { Total } \\
n(\%)\end{array}$ & $\begin{array}{c}\text { Positive wheezing } \\
\text { in last } 12 \text { months } \\
n(\%)\end{array}$ & $\begin{array}{c}\text { No wheezing } \\
\text { in last } 12 \text { months } \\
n(\%)\end{array}$ & $\begin{array}{c}\text { OR }(95 \% \mathrm{Cl})^{*} \\
\text { logistic regression }\end{array}$ & $P$ value \\
\hline \multicolumn{6}{|l|}{ Rhinitis in last 12 months } \\
\hline No & $2284(73.1)$ & $178(42.2)$ & $2106(77.8)$ & 1 & \\
\hline Yes & $844(26.9)$ & $244(57.8)$ & $600(22.2)$ & $4.81(3.89-5.96)$ & $<0.001$ \\
\hline \multicolumn{6}{|l|}{ Eczema ever } \\
\hline No & $2359(75.4)$ & $235(55.7)$ & $2124(78.5)$ & 1 & \\
\hline Yes & 769 (24.6) & $187(44.3)$ & $582(21.5)$ & $2.90(2.35-3.59)$ & $<0.001$ \\
\hline \multicolumn{6}{|c|}{$\begin{array}{l}\text { Cooking fuel used at home } \\
\text { Electricity }\end{array}$} \\
\hline No & 2876 (91.9) & $383(90.8)$ & $2493(92.1)$ & 1 & \\
\hline Yes & $252(8.1)$ & $39(9.2)$ & $213(7.9)$ & $1.19(0.83-1.71)$ & 0.336 \\
\hline \multicolumn{6}{|c|}{ 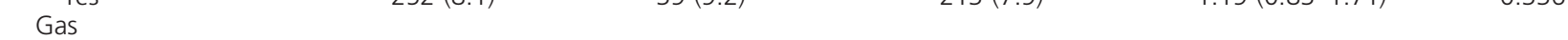 } \\
\hline No & $2(0.1)$ & 0 & $2(0.1)$ & - & 0.576 \\
\hline Yes & 3126 (99.9) & $422(100)$ & 2704 (99.9) & & \\
\hline \multicolumn{6}{|l|}{ Coal } \\
\hline No & $2832(90.6)$ & $377(89.3)$ & $2455(90.8)$ & 1 & \\
\hline Yes & $295(9.4)$ & $45(10.7)$ & $250(9.2)$ & $1.17(0.84-1.64)$ & 0.353 \\
\hline \multicolumn{6}{|l|}{ Other } \\
\hline No & $3128(100)$ & $422(100)$ & $2706(100)$ & - & - \\
\hline Yes & 0 & 0 & 0 & & \\
\hline \multicolumn{6}{|c|}{ Indoor home cooling system } \\
\hline \multicolumn{6}{|c|}{ Split air conditioner } \\
\hline No & $1851(59.2)$ & $220(52.1)$ & $1631(60.3)$ & 1 & \\
\hline Yes & $1277(40.8)$ & $202(47.9)$ & $1075(39.7)$ & $1.39(1.13-1.71)$ & 0.002 \\
\hline \multicolumn{6}{|l|}{ Window air conditioner } \\
\hline No & $2472(79.0)$ & $347(82.2)$ & $2125(78.5)$ & 1 & \\
\hline Yes & $656(21.0)$ & $75(17.8)$ & $581(21.5)$ & $0.79(0.61-1.03)$ & 0.083 \\
\hline \multicolumn{6}{|l|}{ Fan } \\
\hline No & $1690(54.1)$ & $244(57.8)$ & $1446(53.5)$ & 1 & \\
\hline Yes & $1436(45.9)$ & $178(42.2)$ & $1258(46.5)$ & $0.84(0.68-1.03)$ & 0.096 \\
\hline \multicolumn{6}{|l|}{ Other } \\
\hline No & $3128(100)$ & $422(100)$ & $2706(100)$ & - & - \\
\hline Yes & 0 & 0 & 0 & & \\
\hline \multicolumn{6}{|l|}{ None } \\
\hline No & $3034(97.0)$ & $410(97.2)$ & $2624(97.0)$ & 1 & \\
\hline Yes & $94(3.0)$ & $12(2.8)$ & $82(3.0)$ & $0.94(0.51-1.73)$ & 0.834 \\
\hline \multicolumn{6}{|c|}{ Frequency of paracetamol intake } \\
\hline Never & $442(14.1)$ & $39(9.2)$ & 403 (14.9) & 1 & \\
\hline$\geqslant$ once/year & $1289(41.2)$ & $175(41.5)$ & $1114(41.2)$ & $1.62(1.13-2.34)$ & 0.009 \\
\hline$\geqslant$ once/month & $1396(44.6)$ & $208(49.3)$ & $1188(43.9)$ & $1.81(1.26-2.59)$ & 0.001 \\
\hline Number of siblings & & & & & \\
\hline Mean \pm SD & $4.5 \pm 2.7$ & $4.5 \pm 2.8$ & $4.5 \pm 2.7$ & - & $0.850^{\dagger}$ \\
\hline Median (amplitude) & $4(0-24)$ & $4(0-17)$ & $4(0-24)$ & & \\
\hline Frequency of passage of & in front of ho & & & & \\
\hline Never & $374(12.0)$ & $40(9.5)$ & $334(12.3)$ & 1 & \\
\hline Seldom & $1163(27.2)$ & $150(35.5)$ & $1013(37.4)$ & $1.236(0.85-1.79)$ & 0.261 \\
\hline Frequently in the day & $1051(33.6)$ & $147(34.8)$ & $904(33.4)$ & $1.36(0.94-1.97)$ & 0.106 \\
\hline Almost the whole day & $539(17.2)$ & $85(20.1)$ & $454(16.8)$ & $1.56(1.05-2.34)$ & 0.029 \\
\hline Pets at home & & & & & \\
\hline Cat & & & & & \\
\hline No & $2626(84.0)$ & $348(82.5)$ & $2278(84.2)$ & 1 & \\
\hline Yes & $502(16.0)$ & $74(17.5)$ & $428(15.8)$ & $1.13(0.86-1.49)$ & 0.371 \\
\hline Dog & & & & & \\
\hline No & $1317(42.1)$ & $159(37.7)$ & $1158(42.8)$ & 1 & \\
\hline Yes & $1811(57.9)$ & $263(62.3)$ & $1548(57.2)$ & $1.24(1.00-1.53)$ & 0.048 \\
\hline Cat and dog & & & & & \\
\hline No & $2788(89.1)$ & 371 (87.9) & $2417(89.3)$ & 1 & \\
\hline Yes & $340(10.9)$ & $51(12.1)$ & $289(10.7)$ & $1.15(0.84-1.58)$ & 0.388 \\
\hline Smoking at home & & & & & \\
\hline Mother & & & & & \\
\hline No & $3043(97.3)$ & $406(96.2)$ & 2637 (97.5) & 1 & \\
\hline Yes & $85(2.7)$ & $16(3.8)$ & $69(2.5)$ & $1.51(0.87-2.62)$ & 0.145 \\
\hline Father & & & & & \\
\hline No & $2878(92.0)$ & $382(90.5)$ & $2496(92.2)$ & 1 & \\
\hline Yes & $250(8.0)$ & $40(9.5)$ & $210(7.8)$ & $1.25(0.87-1.78)$ & 0.226 \\
\hline Number of smokers $>$ & & & & & \\
\hline No & $2668(85.3)$ & $352(83.4)$ & $2316(85.6)$ & 1 & \\
\hline Yes & $460(14.7)$ & $70(16.6)$ & $390(14.4)$ & $1.18(0.89-1.56)$ & 0.241 \\
\hline
\end{tabular}


Table 5 (continued)

\begin{tabular}{|c|c|c|c|c|c|}
\hline Risk factors & $\begin{array}{l}\text { Total } \\
n(\%)\end{array}$ & $\begin{array}{c}\text { Positive wheezing } \\
\text { in last } 12 \text { months } \\
n(\%)\end{array}$ & $\begin{array}{c}\text { No wheezing } \\
\text { in last } 12 \text { months } \\
n(\%)\end{array}$ & $\begin{array}{c}\text { OR }(95 \% \mathrm{Cl})^{*} \\
\text { logistic regression }\end{array}$ & $P$ value \\
\hline \multicolumn{6}{|l|}{ BMI } \\
\hline Normal weight, kg & $714(44.6)$ & $187(44.3)$ & $554(44.7)$ & 1 & \\
\hline Mean $\mathrm{BMI} \pm \mathrm{SD}$ & $20.4 \pm 1.5$ & $20.4 \pm 1.5$ & $20.4 \pm 1.5$ & & \\
\hline Underweight, kg & $854(51.4)$ & $212(50.2)$ & $642(51.9)$ & $0.978(0.78-1.23)$ & 0.850 \\
\hline Mean BMI \pm SD & $16.7 \pm 1.4$ & $16.8 \pm 1.6$ & $16.6 \pm 1.3$ & & \\
\hline Overweight; kg & 65 (3.9) & $23(35.4)$ & $42(3.4)$ & & \\
\hline Mean BMI \pm SD & $28.3 \pm 3.3$ & $28.1 \pm 3.1$ & $28.4 \pm 3.4$ & $1.62(0.95-2.77)$ & 0.076 \\
\hline Obese & 0 & 0 & 0 & - & \\
\hline
\end{tabular}

* For each categorical variable, the 'normal' situation was defined as the reference category and odds were estimated for the other categories against the reference category.

Student's t-test.

$\mathrm{OR}=$ odds ratio; $\mathrm{Cl}=$ confidence interval; $\mathrm{SD}=$ standard deviation; $\mathrm{BMI}=$ body mass index .

Luanda Province and from relatively wealthy families. Further studies should also incorporate adolescents from poorer, rural areas. In addition, we could not use the ISAAC video for comparison with the written questionnaire, and so may have missed some adolescents with asthma who failed to identify symptoms on the questionnaire but would have recognised them on the video. ${ }^{33}$ Some potentially important risk factors, such as family history of asthma, other allergies or sensitisation to aeroallergens, were not included in our analysis, which may have impaired comparisons with similar studies in other populations. Although the ISAAC questionnaire on environmental exposure has been validated, the level of detail may not be sufficient for some of the risk factors, such as exposure to traffic fumes or the type of cooking (i.e., open fire cooking, which is associated with an increased risk of asthma ${ }^{34}$ ). Finally, the cross-sectional design of the study did not allow the clarification of the interrelationships between different diseases in terms of complex patterns of multimorbidity. ${ }^{35}$

\section{CONCLUSION}

Our results demonstrate that asthma and other allergic diseases are a public health problem in Luanda, and also that a high proportion of adolescents with asthma are frequently symptomatic but are not treated by physicians. It is therefore crucial to develop prevention and management plans as well as to increase accessibility to health care to adequately deal with these problems.

\section{Acknowledgements}

The authors would like to thank all the Directory Boards of all schools involved in the study, and all the adolescents and their parents/guardians.

Questionnaire copies were supplied by AstraZeneca, Anpola, Luanda, Angola, and Merck Sharp \& Dohme Angola, Luanda, Angola. Peak flow meters were supplied by GlaxoSmithKline, Anpola, Luanda, Angola. No drug company had any input in the design or implementation of the study.

Conflicts of interest: OL, FQ, JMRG and JRP have no conflicts of interest and were not funded. MA has received support to attend international congresses from Merck Sharp \& Dohme and from AstraZeneca. LTB has received support to attend European Academy of Allergy and Clinical Immunology congresses from Vitoria Laboratories (Lisbon, Portugal) and Menarini, Winnersh, UK; and has been paid lecture fees by Novartis (Basel, Switzerland), AstraZeneca, Merck Sharp \& Dohme and Menarini.

\section{References}

1 Asher I, Pearce N. Global burden of asthma among children. Int J Tuberc Lung Dis 2014; 18: 1269-1278.

2 Asher M I, Montefort S, Björkstén B, et al. Worldwide time trends in the prevalence of symptoms of asthma, allergic rhinoconjunctivitis, and eczema in childhood: ISAAC Phases One and Three repeat multicountry cross-sectional surveys. Lancet 2006; 368: 733-743.

3 Anandan C, Nurmatov U, Van Schayck O C P, Sheikh A. Is the prevalence of asthma declining? Systematic review of epidemiological studies. Allergy 2010; 65: 152-167.

4 International Study of Asthma and Allergies in Childhood. Phase Three Manual. Auckland, New Zealand: ISAAC, 2000. http:// isaac.auckland.ac.nz/phases/phasethree/phasethreemanual.pdf. Accessed February 2017.

5 Rosado-Pinto J. ISAAC-20 anos em Portugal. Acta Ped Port 2011; 42 (Suppl II): S35-S37.

6 International Study of Asthma and Allergies in Childhood. ISAAC tools. Auckland, New Zealand: ISAAC, 2015. http:// isaac.auckland.ac.nz/resources/tools.php? menu=tools1. Accessed February 2017.

7 Ait-Khaled N, Odhiambo J, Pearce N, et al. Prevalence of symptoms of asthma, rhinitis and eczema in 13- to 14-year-old children in Africa: The International Study of Asthma and Allergies in Childhood Phase III. Allergy Eur J Allergy Clin Immunol 2007; 62: 247-258.

8 Boaventura C M, Amuy F F, Franco J H, et al. Peak expiratory flow rate reference values in students. Arq Med ABC 2007; 32 (Suppl 2): S30-S34.

9 de Onis M, Onyango A W, Borghi E, Siyam A, Nishida C, Siekmann J. Development of a WHO growth reference for school-aged children and adolescents. Bull World Health Organ 2007; 85: 660-667.

10 Asher M I, Keil U, Anderson H R, et al. International study of asthma and allergies in childhood (ISAAC): rationale and methods. Eur Respir J 1995; 8: 483-491.

11 Wandalsen N, Gonzalez C, Wandalsen G, Sole D. Evaluation of criteria for the diagnosis of asthma using an epidemiological questionnaire. J Bras Pneumol 2009; 35: 199-205.

12 Mallol J, Crane J, Von Mutius E, Odhiambo J, Keil U, Stewart A. The International Study of Asthma and Allergies in 
Childhood (ISAAC) Phase Three: a global synthesis. Allergol Immunopathol 2012; 41: 73-85.

13 Ait-Khaled N, Odhiambo J, Pearce N, et al. Prevalence of symptoms of asthma, rhinitis and eczema in 13- to 14-year-old children in Africa: the International Study of Asthma and Allergies in Childhood Phase III. Allergy 2007; 62: 247-258.

14 Mavale-Manuel S, Joaquim O, Macome C, et al. Asthma and allergies in schoolchildren of Maputo. Allergy 2007; 62: 265271.

15 Zar H, Ehrlich R, Workman L, Weinberg E. The changing prevalence of asthma, allergic rhinitis and atopic eczema in African adolescents from 1995 to 2002. Pediatr Allergy Immunol 2007; 18: 560-565.

16 Ait-Khaled N, Pearce N, Anderson H R, et al. Global map of the prevalence of symptoms of rhinoconjunctivitis in children: The International Study of Asthma and Allergies in Childhood (ISAAC) Phase Three. Allergy 2009; 64: 123-148.

17 Odhiambo J A, Williams H C, Clayton T O, Robertson C F, Asher M I, ISAAC Phase Three Study Group. Global variations in prevalence of eczema symptoms in children from ISAAC Phase Three. J Allergy Clin Immunol 2009; 124; 1251-1258.

18 Beasley R; ISAAC Steering Committee. Worldwide variation in prevalence of symptoms of asthma, allergic rhinoconjunctivitis, and atopic eczema: ISAAC. Lancet 1998; 351: 1225-1232.

19 Georgy V, Fahim H I, El-Gaafary M, Walters S. Prevalence and socio-economic associations of asthma and allergic rhinitis in nothern Africa. Eur Respir J 2006; 28: 756-762.

20 Mavale-Manuel S, Alexandre F, Duarte N, Albuquerque O, Scheinmann P, Blic J. Risk factors for asthma among children in Maputo (Mozambique). Allergy 2004; 59: 388-393.

21 Brescianini S, Brunetto B, Iacovacci P, et al. Prevalence of selfperceived allergic diseases and risk factors in Italian adolescents. Pediatr Allergy Immunol 2009; 20: 578-584.

22 Garcia E, Aristizabal G, Vasquez C, Rodriguez-Martinez C E, Sarmiento L, Satizabal C L. Prevalence of and factors associated with current asthma symptoms in school children aged 6-7 and 13-14 yr old in Bogotá, Colombia. Pediatr Allergy Immunol 2008; 19: 307-314.

23 Guerra S, Sherrill D L, Martinez F D, Barbee R A. Rhinitis as an independent risk factor for adult-onset asthma. J Allergy Clin Immunol 2002: 109: 419-425.

24 Anderson H R, Bland J M, Peckham C S. Risk factors for asthma up to 16 years of age. Evidence from a national cohort study. Chest 1987; 91 (Suppl): 127S-130S.
25 Ballardini N, Bergström A, Böhme M, et al. Infantile eczema: prognosis and risk of asthma and rhinitis in preadolescence. $\mathrm{J}$ Allergy Clin Immunol 2014; 133: 594-596.

26 Liu Z, Bai Y. Detection of dermatophagoides farinae in the dust of air conditioning filters. Int Arch Allergy Immunol 2007; 144: 85-90.

27 Tang S P, Liu Y L, Wang S B, et al. Trends in prevalence and risk factors of childhood asthma in Fuzhou, a city in Southeastern China. J Asthma 2015; 52: 10-15.

28 Zuraimi M S, Tham K W, Chew F T, Ooi P L, Koh D. Home airconditioning, traffic exposure, and asthma and allergic symptoms among preschool children. Peadiatr Allergy Immunol 2011; 22: e112-e118.

29 Beasley R W, Clayton T O, Crane J, et al. Acetaminophen use and risk of asthma, rhinoconjunctivitis, and eczema in adolescents: International study of asthma and allergies in childhood phase three. Am J Respir Crit Care Med 2011; 183: 171-178.

30 Newson R B, Shaheen S O, Chinn S, Burney P G. Paracetamol sales and atopic disease in children and adults: an ecological analysis. Eur Respir J 2000; 16: 817-823.

31 Eneli I, Sadri K, Camargo C, Jr, Barr R G. Acetaminophen and the risk of asthma: the epidemiologic and pathophysiologic evidence. Chest 2005; 127: 604-612.

32 Flohr C, Weinmayr G, Weiland S K, et al. How well do questionnaires perform compared with physical examination in detecting flexural eczema? Findings from the International Study of Asthma en Allergies in Childhood (ISAAC) Phase Two. Br J Dermatol 2009; 161: 846-853.

33 Crane J, Mallol J, Stewart A, Asher M I, on behalf of the International Study of Asthma and Allergies in Childhood (ISAAC) Phase I Study Group. Eur Respir J 2003; 21: 455-461.

34 Wong G W, Brunekreef B, Ellwood P, et al. Cooking fuels and prevalence of asthma: a global analysis of phase three of the International Study of Asthma and Allergies in Childhood (ISAAC). Lancet Respir Med 2013; 1: 386-394.

35 Pinart M, Benet M, Annsei-Maesano I, et al. Comorbidity of eczema, rhinitis, and asthma in IgE-sensitised and non-IgEsensitised children in MeDALL: a population-based cohort study. Lancet Respir Med 2014; 2: 131-140. 
CONTEXTE: Les rares études épidémiologiques sur l'asthme et les maladies allergiques réalisées en Afrique ont montré que leur prévalence était élevée ou croissante. Aucune de ces études n'a été réalisée en Angola.

O B JECTIF : Déterminer la prévalence de l'asthme et des autres maladies allergiques chez les adolescents Angolais.

SCHÉMA : Étude descriptive, d'observation, transversale, avec la méthode International Study of Asthma and Allergies in Childhood, dans la province de Luanda, Angola, chez des adolescents âgés de 13 et 14 ans. Vingt-trois $(\mathbf{1 2} \%)$ écoles publiques ont été sélectionnées au hasard. Les données ont été analysées avec le logiciel Statistical Package for the Social Sciences version 22.0.

RÉ SULTATS : Au total, 3128 adolescents ont été inclus.
La prévalence de l'asthme (wheezing au cours des 12 derniers mois) a été de $13,4 \%$. La prévalence de la rhinite (éternuements, rhinorrhée ou nez bouché au cours des 12 derniers mois) a été de $27 \%$ et celle de l'eczéma (lésions prurigineuses de la peau au cours des 12 derniers mois) a été de $20 \%$, les deux étant plus prévalents chez les filles. La rhinite a été associée à un plus grand nombre d'épisodes de toux nocturne chez les adolescents atteints d'asthme. La rhinite et l'eczéma, les systèmes de climatisation split-type et la prise fréquente (plus d'une fois par mois) de paracétamol ont été associés à un risque plus élevé d'avoir de l'asthme.

CONCLUSION: L'asthme et les maladies allergiques associées sont un problème de santé publique chez les adolescents de Luanda. Des mesures de prévention et de lutte devraient être mises en œuvre.
MARCO DE REFERENCIA: Algunas investigaciones epidemiológicas realizadas en África sobre el asma y las enfermedades alérgicas han puesto en evidencia que la prevalencia es alta o tiende a aumentar. Ningún estudio sobre este tema se ha llevado a cabo en Angola. O BJETIVO: Determinar la prevalencia de asma y otras enfermedades alérgicas en los adolescentes angoleños. MÉTO D O: Se concibió un estudio transversal descriptivo observacional con base en el diseño del estudio internacional, International Study of Asthma and Allergies in Childhood, con adolescentes de 13 y 14 años de edad de Luanda, en Angola. Se escogieron de manera aleatoria 23 escuelas públicas $(12 \%)$. Los datos se analizaron con la versión 22.0 del programa estadístico informático, Statistical Package for the Social Sciences.

RESULTADOS: Se incluyeron en el estudio 3128 adolescentes. La prevalencia se definió por la presencia de signos en los últimos 12 meses. La prevalencia de asma fue $13,4 \%$ (sibilancias). La prevalencia de rinitis fue $27 \%$ (estornudos, rinorrea u obstrucción nasal) y la de eccema fue $20 \%$ (lesiones cutáneas pruriginosas); ambas entidades fueron más frecuentes en las niñas. La rinitis se asoció con un mayor número de episodios de tos nocturna en los adolescentes con asma. Se observó que existía una relación entre la presencia de rinitis y eccema, el sistema de aire acondicionado modular con varias unidades y la ingesta frecuente de paracetamol (más de una vez al mes) y un mayor riesgo de padecer asma.

CONCLUSIÓN: El asma y las enfermedades alérgicas afines en los adolescentes de Luanda representan un problema de salud pública. Es preciso adoptar medidas preventivas y de control. 